\title{
Pleurotus ostreatus as a Biodegradator for Organophosphorus Insecticide Malathion
}

\section{Ganash MA ${ }^{1}$, Abdel Ghany $\mathrm{TM}^{2,3}$ and Reyad $\mathrm{AM}^{4^{\star}}$}

${ }^{1}$ Department of Biology, Faculty of Science, King Abdulaziz University, Jeddah, Saudi Arabia

${ }^{2}$ Botany and Microbiology Department, Faculty of Science, Al-Azhar University, Egypt

${ }^{3}$ Biology Department, Faculty of Science, Jazan University, Jazan, Saudi Arabia

${ }^{4}$ Botany Dept. Faculty of Science, Beni-Suef University, Egypt

\begin{abstract}
Excessive and continuous use of organophosphorus insecticides as well as malathion has led to the contamination of ecosystems in several rejoins of the world. For its degradation in the ecosystems usage of the microbes has been proved to be the effective method for controlling ecosystems pollution. Biodegradation of pesticides by using microbes have more advantages over the conventional methods. In the present investigation therefore attempts have been made to make use of white rot fungus Pleurotus ostreatus for malathion degradation. Malathion rest quantity at 5,15 and 25 days was 40.5, 22.6 and $11.8(\mu \mathrm{g} / 100 \mathrm{~mL})$ with degradation \% 19.0, 54.8 and 76.4 respectively at initial concentration $(50 \mu \mathrm{g} / 100 \mathrm{~mL})$. Lignin peroxidase, manganese peroxidase, and laccase production was stimulated with the presence of malathion. At $25 \mu \mathrm{g} / 100 \mathrm{~mL}$ malathion, productivity of lignin peroxidase, manganese peroxidase, and laccase was 0.51 , 0.57 and $4.30 \mathrm{U} / \mathrm{ml}$ respectively compared with the control (growth medium without malathion). At low concentrations of malathion $(25$ and $50 \mu \mathrm{g}) P$. ostreatus productivity of these enzymes was more, but at high concentration of malathion the productivity was less than control. Addition of lignin compound induced the productivity of ligninolytic enzymes and therefore the biodegradation of malathion was increased. GC/MS analysis revealed the presence of many products as a result of malathion biodegradation including diethyl mercaptosuccinate, methy I,2-(Dimethoxyphosphoryl)-2-(1,2,3thiadiazol-4-yl) acetate, 3,4-dihydrothienyl (3,4,b)-5-carboxythiophene, Butanedioic acid, 2,2'-Thiodisuccinic acid; 1,1-Dimethyltetradecyl hydrosulfide and Disulfide, di-tert-dodecyl.
\end{abstract}

Keywords: Whit rot-fungus; Pleurotus ostreatus; Biodegradator; Malathion

\section{Introduction}

Organophosphorus compound poisoning is a worldwide health problem with around three million poisonings and 200000 deaths annually $[1,2]$. Continuous and excessive use of organophosphorus compounds has led to the contamination of several ecosystems in different parts of the world [3-5]. Malathion [S-(1,2dicarbethoxyethyl)-O,O-dimethyldi-thiophosphate], also known as maldison, carbophos and mercaptothion is a nonsystemic, widespectrum organophosphorus insecticide used to control the household and agricultural pests. According to Singh et al. [6] malathion was recognized as the first organophosphorous insecticide with highly selective toxicity. Malathion is an organophosphate insecticide and acaricide that has been suited for the control of sucking and chewing insects on field crops, fruits, vegetable, livestock, and also extensively used to prevent mosquitoes, flies, household insect, animal parasites, and head body lice as substitute for DTT compound $[7,8]$. Malathion in soil undergo a variety of transformations that provide a complex pattern of metabolites and its fate in soil is controlled by chemical, biological and physical dynamics of this matrix. Products resulted from malathion degradation include dimethyl phosphate, dimethyldithiophosphate, dimethylthiophosphate, isomalathion, malaoxon and malathion mono and dicarboxylic acid due to enzymatic activity of cutinase, carboxylesterase, phosphatase [9]. Malathion itself is of low toxicity, it mainly concentrates in peel and may not readily removed by washing in water alone [10], but easily enter the body through absorption through the skin, ingestion and inhalation results in its metabolism to malaoxon which is substantially more toxic [11]. Long-term exposure to oral ingestion of malaoxon in rats, showed 61 times more toxic than malathion.

Today, microorganisms are used in bioremediation of environmental pollutants. Using microorganisms is natural process, very effective when compared to the other methods and applicable for insitu bioremediation. Biodegradation of organophosphate compounds releases phosphate as one of the end product [12]. Fungi [13] are capable of degrading malathion. Ahmed et al. [14] found that the degradation rate of malathion by bacterial was slower than the fungal isolates. White rot fungi as a group include Phanerochaete chrysosporium, Trametes versicolor, Pleurotus ostreatus, Bjerkandera adusta, and Pleurotus tuberregium. On the basis of their ability to secrete extracellular lignin-degrading enzymes, these fungi have been applied in bioremediation studies [15]. White-rot fungi can degrade a wide spectrum of recalcitrant organopollutants, often carcinogenic, mutagenic or toxic, that arise from industrial operations, petroleum released into environment and plant protection [16]. Pleurotus ostreatus is a commercially important edible mushroom [17]. Most of the white-rot fungi secrete various extra cellular enzymes that degrade a large range of natural and anthropogenic compounds that have structural and chemical similarities to the lignin substructure. Among them, peroxidase or ligninolytic enzymes, predominantly lignin peroxidase (LiP), manganese peroxidase $(\mathrm{MnP})$ and laccase. Presence of nonspecific enzyme system, enable fungi to degrade natural complex aromatic polymers of lignin as well as complex aromatic polymers

*Corresponding author: Abdel Ghany TM, Biology Department, Faculty of Science, Jazan University, Jazan, Saudi Arabia, Tel: 00201015386248; E-mail: tabdelghany@yahoo.com

Received October 01, 2015; Accepted April 30, 2016; Published May 04, 2016

Citation: Ganash MA, Abdel Ghany TM (2016) Pleurotus ostreatus as a Biodegradator for Organophosphorus Insecticide Malathion. J Environ Anal Toxicol 6: 369. doi:10.4172/2161-0525.1000369

Copyright: (c) 2016 Ganash MA, et al. This is an open-access article distributed under the terms of the Creative Commons Attribution License, which permits unrestricted use, distribution, and reproduction in any medium, provided the original author and source are credited. 
that share structure with lignin, such as pesticides, PAHs, PCBs and dyes [18]. Several studies stated that potential applications of whiterot fungi and their enzymes are gaining increasing importance in the detoxification of industrial waste waters, biodegradation, biopulping, degradation and detoxification of recalcitrant substances [19-23]. The present work was aimed at studying the ability of a white-rot fungus Pleurotus ostreatus, as a biodegratator of insecticide malathion. Optimal conditions for the biodegradation were also explored.

\section{Materials and Methods}

\section{Biodegradator used}

Pleurotus ostreatus (obtained from agricultural ministry, Egypt) was cultivated on Malt agar plates for 10 days at $30^{\circ} \mathrm{C}$. Mycelium agar plugs $9 \mathrm{~mm}$ in diameter (cut along the edge of an actively growing colony) were used as inocula.

\section{Fungal degradation of organophosphrus insecticides at different incubation period}

Mineral salt liquid medium supplemented with $50 \mu \mathrm{g} / 100 \mathrm{~mL}$ concentration of analytical grade standard of Malathion (Figure 1) was used for biodegradation test at 5,15 and 25 days.

\section{Effect of different concentrations of malathion on fungal growth}

Different concentrations of malathion 25,50 and $100 \mu \mathrm{g} / 100 \mathrm{~mL}$ were added to growth medium. Fungal mycelia (disc $0.5 \mathrm{~cm}$ ) were transferred to growth medium and incubated at $28 \pm 2^{\circ} \mathrm{C}$ for 10 days.

\section{Lignin as inducer to malathion degradation at different concentrations and ligninolytic enzymes detection}

Mineral salt liquid medium supplemented with various concentrations of malathion $(25,50$ and $100 \mu \mathrm{g} / 100 \mathrm{~mL})$ was autoclaved. Then, $0.2 \mathrm{~g} \%$ of lignin was added to growth medium, in order to test the ability of the fungus to produce ligninolytic enzymes which enhance the biodegradation of malathion. Flasks containing medium were inoculated with fungus and then incubated at $30^{\circ} \mathrm{C}$ for 15 days. After incubation period the malathion rest quantity was extracted for quantitative analysis and the metabolized medium was filtrate through filter paper, and used for assay of three enzymes lignin peroxidase (LIP), laccase (phenol oxidase), manganese peroxidase (MnPase). LIP activity was assayed using veratryl alcohol as a substrate. LIP catalyzes the oxidation of veratryl alcohol by $\mathrm{H}_{2} \mathrm{O}_{2}$ to veratryl aldehyde. The aldehyde was absorbed strongly at $310 \mathrm{~nm}$ after incubation for $1 \mathrm{~h}$ at $37^{\circ} \mathrm{C}$. The reaction medium contained: $1 \mathrm{~mL}$ of the enzyme solution (culture filtrate), $0.2 \mathrm{~mL}$ of $2 \mathrm{mmol} / \mathrm{L}$ veratryl alcohol, $0.2 \mathrm{~mL}$ of $0.4 \mathrm{mmol} / \mathrm{L} \mathrm{H}_{2} \mathrm{O}_{2}, 0.2 \mathrm{~mL}$ of $0.25 \mathrm{mmol} / \mathrm{L}$ tartaric acid. Laccase activity is determined by the oxidation of $2,2 \$$-azino-bis<smiles>CCOC(=O)CC(SP(=S)(OC)OC)C(=O)OCC</smiles>

Figure 1: Malathion chemical structure. (3-ethylthiazoline-6-sulfonate), i.e., $\mathrm{ABTS}$ at $37^{\circ} \mathrm{C}$ at $\mathrm{A} 420$ [24]. One unit of enzyme activity is defined as the amount of enzyme oxidizing 1 mMol of ABTS per minute. Reaction mixture of $1 \mathrm{ml}$ contained $2 \mathrm{mM}$ of ABTS in a Mcllvaine buffer ( $\mathrm{pH}$ 5.0). To the assay mixture, $100 \mu \mathrm{l}$ of centrifuged extracellular supernatants were added. The enzymatic activity was estimated in IU by monitoring the adsorbance change at $420 \mathrm{~nm}$ (ABTS), $€=36 \mathrm{Mm}^{-1} \mathrm{~cm}^{-1}$ by spectrophotometer (UVikon $\mathrm{XS} / 60 / 99-90289$; Volt $110 / 240 \mathrm{~V}$ ) at $30^{\circ} \mathrm{C}$. MnPase activity was carried out in $1 \mathrm{~cm}$ quartz cuvette. The reaction mixture of $1 \mathrm{ml}$ contained 2 $\mathrm{mM}$ of ABTS and $1 \mathrm{mM} \mathrm{Mn}^{2+}$ in a Mcllvaine buffer ( $\mathrm{pH}$ 5.0). To the assay mixture, $100 \mu \mathrm{l}$ of centrifuged extra cellular fluids (supernatants) were added. The peroxidase activity was then initiated by the addition of $0.4 \mathrm{mM} \mathrm{H}_{2} \mathrm{O}_{2}[25,26]$. The enzymatic activity was estimated in IU by monitoring the adsorbance change at $420 \mathrm{~nm}$ (ABTS), $€=36 \mathrm{mM}^{-1} \mathrm{~cm}^{-1}$ by spectrophotometer at $30^{\circ} \mathrm{C}$.

\section{Gas Chromatography/Mass Spectrometry (GC/MS) analysis of malathion degradation}

The concentrated extract of metabolized medium was extracted with using methanol, then filtrated and concentrated into $1 \mathrm{ml}$ and was placed in GC auto-sampler vials until they were analyzed. A Varian Star 3400 Cx Ion Trap GC/MS Shimadzu GCMS-QP 5050 A. software class 5000. Searched library: Wiley 229 LIB. Column: DBI, $30 \mathrm{~m}$, $053 \mathrm{~mm}$ ID; $1.5 \mathrm{um}$ film. Carrier gas: Helium (flow rate $1 \mathrm{ml} / \mathrm{min}$.) Ionization mode: El $(70 \mathrm{ev})$. Temperature program: 70 (static for 2 min) then gradually increasing (at a rate of $2 / \mathrm{min}$ ) up to 220 (static for $5 \mathrm{~min}$ ). Detector temperature 250 injector temperature 250 The chromatographs were compared and individual peaks were identified by comparing mass spectra to the library references. At the Regional Center for Mycology and Biotechnology AL-Azhar University).

\section{Results and Discussion}

Investigation of microbial degradation is useful for developing insecticide degradation strategies using microorganisms. In the current study, Pleurotus ostreatus growth decreased with increasing malathion concentration (Table 1 and Figure 2). At 25, 50 and $100 \mu \mathrm{g} / 100 \mathrm{~mL}$ malathion, the inhibition \% was $4.62,35.48$ and $64.62 \%$ respectively. Recently, Abbas et al. [27] found that the efficacy of the pesticides on the inhibition of the fungal growth and spore germination showed that they were both reduced with the increasing concentration of the insecticide.

GC/MS analysis of malathion degradation (Figure 3) with using Pleurotus ostreatus at different incubation periods up to 25 days indicated that biodegradation increased with increasing incubation period. Malathion rest quantity at 5, 15 and 25 days was 40.5, 22.6 and $11.8(\mu \mathrm{g} / 100 \mathrm{~mL})$ with degradation $\% 19.0,54.8$ and 76.4 respectively at initial concentration $(50 \mu \mathrm{g} / 100 \mathrm{~mL})$ (Figure 4). Chalamala et al. [13] worked on mycodegradation of Malathion by using A. niger and got $86.72 \%$ of degradation. Recently, research activities in this area have shown that a diverse range of microorganisms are capable of degrading malathion [28]. White-rot fungi tolerate considerable amounts of toxic pollutants, have high surface growth rates [29] and produce extracellular enzymes and other mediators that can reach contaminants that are poorly bioavailable [30].

Pleurotus ostreatus secretes enzymes such as lignin peroxidase, manganese peroxidase, and laccase. These ligninolytic enzymes have been reported to be versatile and nonspecific in their degradation characteristics and can be used in degrading a broad range of aromatic contaminants [31]. In the current study, lignin peroxidase, manganese 


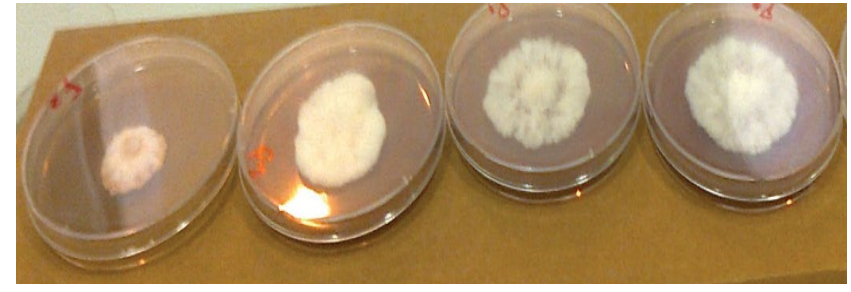

Figure 2: Fungal growth from right to left at control, 25, 50 and $100 \mu \mathrm{g} / 100 \mathrm{~mL}$
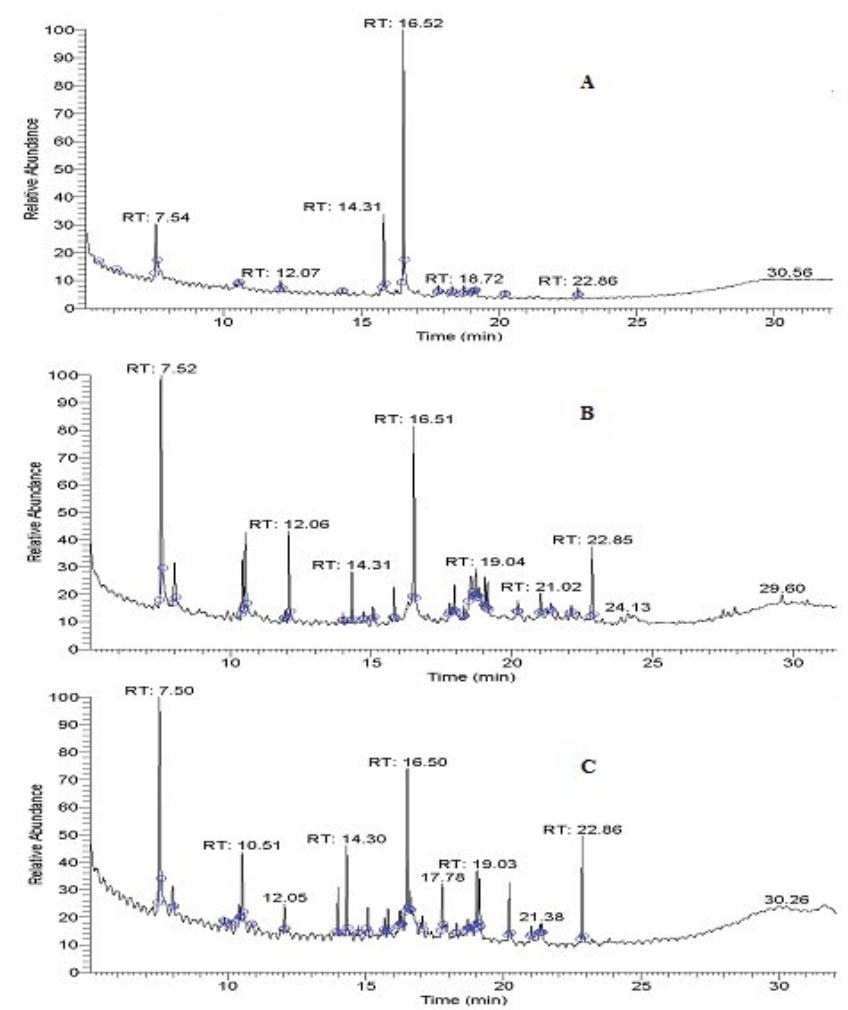

Figure 3: GC/MS of Malathion degradation after different incubation Periods ( $A$ 5 days; $B, 15$ days; $C, 25$ days).

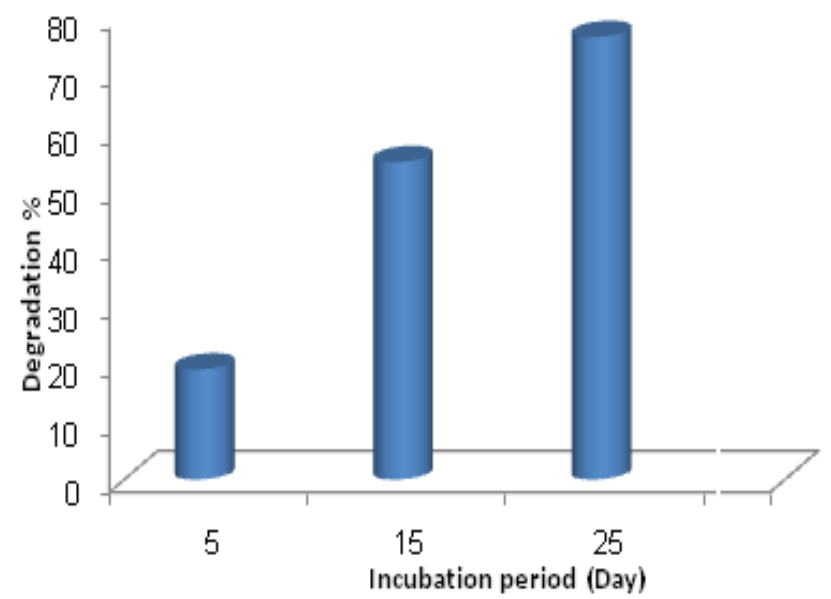

Figure 4: Malathion degradation at different incubation periods at initial concentration $(50 \mu \mathrm{g} / 100 \mathrm{~mL})$

\begin{tabular}{|c|c|c|}
\hline Malathion Concentration & Fungus growth $\mathbf{( c m )}$ & Inhibition \% \\
\hline 0 & 6.5 & 0.00 \\
\hline 25 & 6.2 & 4.62 \\
\hline 50 & 4.2 & 35.48 \\
\hline 100 & 2.3 & 64.62 \\
\hline
\end{tabular}

Table 1: Fungal growth and degradation $\%$ at different concentration of Malathion.

peroxidase, and laccase production was stimulated with the presence of malathion. At $25 \mu \mathrm{g} / 100 \mathrm{~mL}$ malathion, productivity of lignin peroxidase, manganese peroxidase, and laccase was $0.51,0.57$ and 4.30 $\mathrm{U} / \mathrm{ml}$ respectively compared with the control (growth medium without malathion) (Table 2). In previous studies [32,33], production of lignolytic enzymes is indeed known to be stimulated by toxic phenols released during lignin degradation or by toxins released by other organisms and by the presence of aromatic xenobiotic compounds. At low concentrations of malathion $(25$ and $50 \mu \mathrm{g}) P$. ostreatus productivity of these enzymes was more, but at high concentration of malathion the productivity was less than control. Addition of lignin compound induced the productivity of ligninolytic enzymes and therefore the biodegradation of malathion was increased (Table 2). According to many studies [34-36] biodegradation and bioremediation of a large array of organic pollutants, including polycyclic aromatic hydrocarbons, insecticides, polychlorinated aromatic compounds, and synthetic dyes with using white-rot fungi have been successfully. Enzymatic systems of white-rot fungi are capable of oxidative depolymerization and subsequent mineralization of lignin-related compounds [37]. Fungi and bacteria produce intracellular or extracellular enzymes including hydrolytic enzymes, peroxidases, oxygenases [38,39]. According to Xie et al. [40], malathion was completely decomposed within $29 \mathrm{~h}$ at the concentration of $12.860 \mathrm{~g} / \mathrm{L}$. and decreased from 100 to $0 \mathrm{mg} / \mathrm{L}$ in $84 \mathrm{~h}$ with using Acinetobacter johnsonii.

In the present study, GC/MS analysis (Figure 5) revealed that many products as a result of malathion biodegradation including diethyl mercaptosuccinate, methy 1, 2-(Dimethoxyphosphoryl)2-(1,2,3-thiadiazol-4-yl) acetate, 3,4-dihydrothienyl (3,4,b)-5carboxythiophene, Butanedioic acid, 2,2'-Thiodisuccinic acid; 1,1-Dimethyltetradecyl hydrosulfide and Disulfide, di-tert-dodecyl. Kanade et al. [41] reported that six products were obtained with varied functional groups as phosphorothioic acid, o,o,strimethyl ester, phosphorodithioic acid, o,o,strimethyl ester, Butanedioic acid, mercaptoderivative, Succinic acid mercapto diethyl ester, sester with o-s-dimethyl phosphorodithioate, Butanedioic acid [(dimethoxyphosphinothioyl) thio]-,diethyl ester and Succinic acid mercapto diethyl ester, s-ester with o,s-dimethyl phosphorodithioate as a result of microbial degradation of malathion. Our results agreement with Abo-Amer [42], who observed the formation of diethylsuccinate and succinate metabolites when the malathion used as a sole carbon source for Pseudomonas aeruginosa growth. Recently studies [43,44] reported that organophosphate pesticides are degraded by a number of microorganisms through hydrolysis and/or microbial cleavage utilizing phosphatase, oxidoreductases, phosphatases, esterase, hydrolase, and oxygenase into a variety of metabolites like malaoxon, diethylphosphorothioate with subsequent conversion into salt of succinic acid.

\section{Conclusions}

White-rot fungus possesses complex and efficient lignolytic enzyme system. They have been successfully applied in treatment and 

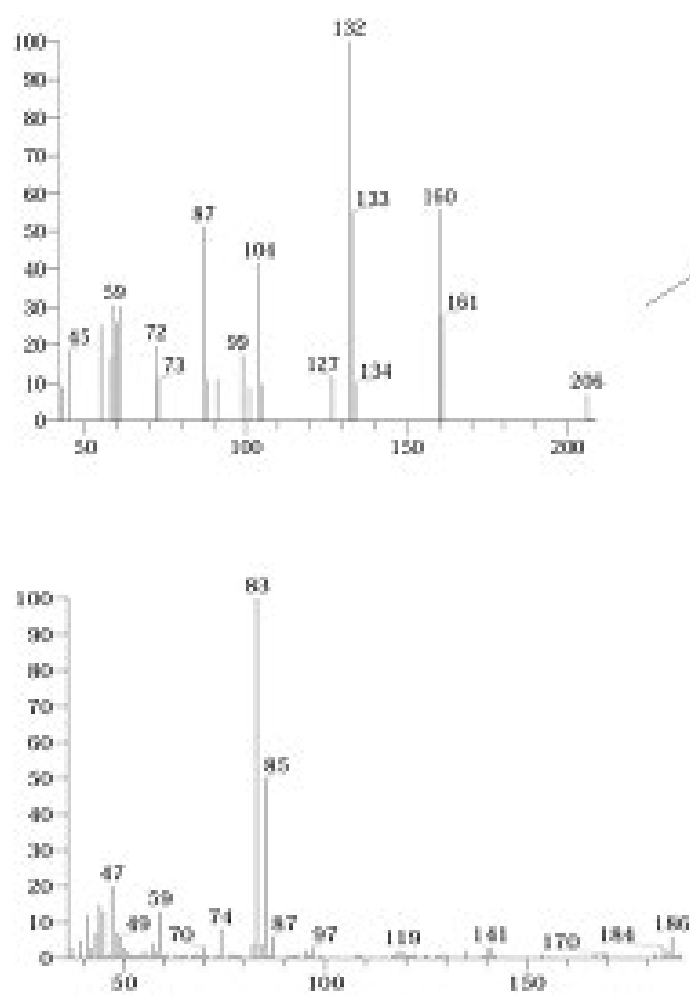

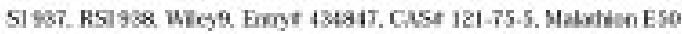
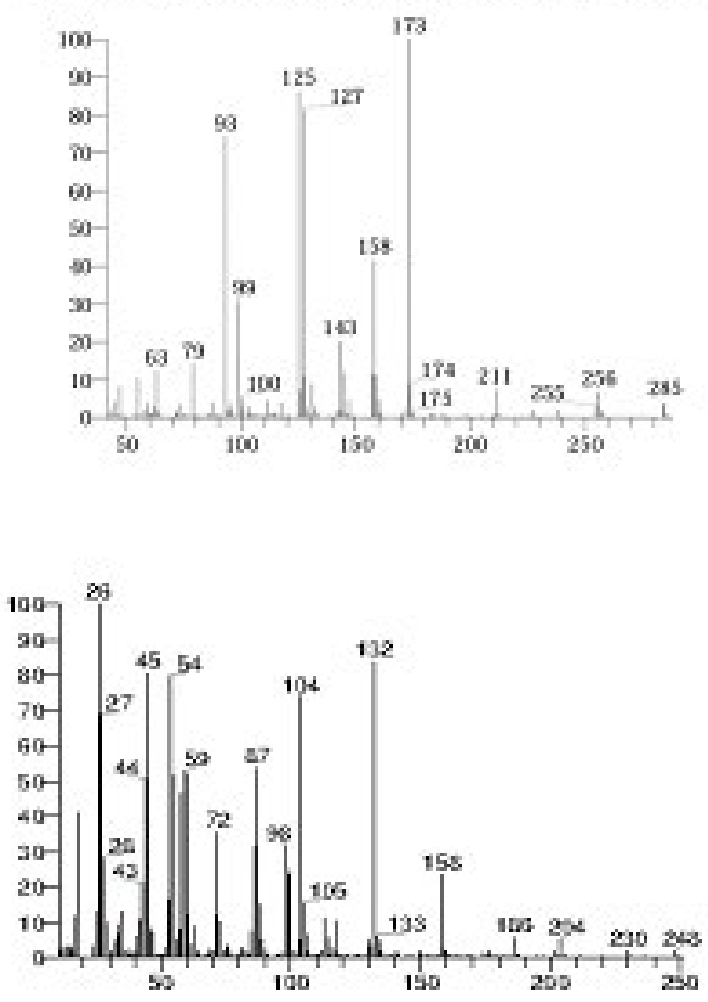

DETHYL MERCAPTOSUCCINATE

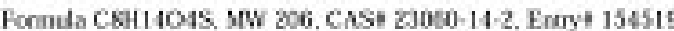

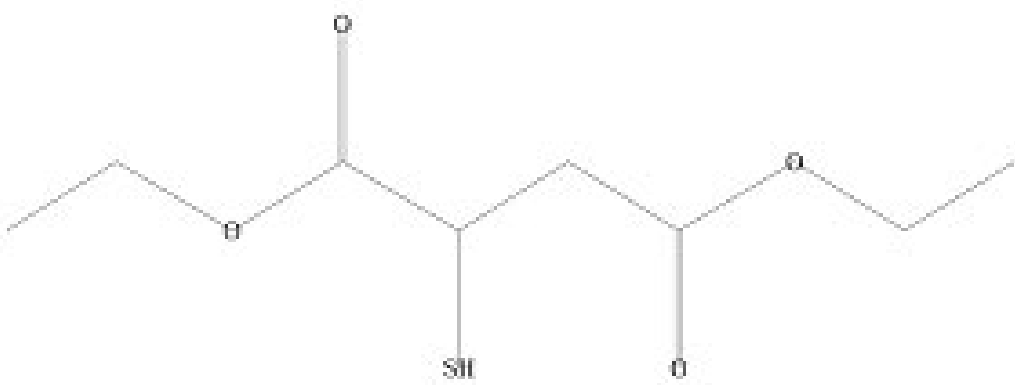

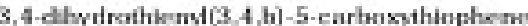
Fomala CJHEO2S2. MW ISG CASE NA Entry" 112502 3.4.DIHYDROTHIENO-43.4-B)-5.CARBOXYTHKOPHENE

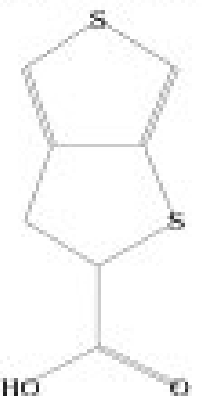

Malation ES0

Formula CI0H1906PSz. MN 390. CASt 121-75-5. Entry 434843

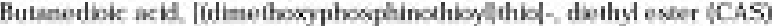

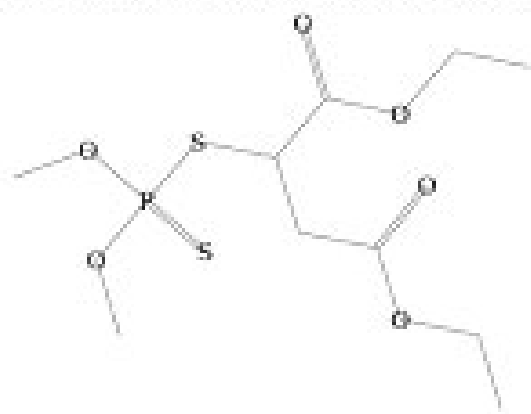

2.2.Thiod succinc acid
Fomula C3H10083, MW 286, CASe 4917-76-4, Erory 4 Thiodauceinie acid<smiles>O=C(O)CC(SC(CC(=O)O)C(O)O)C(=O)O</smiles> 

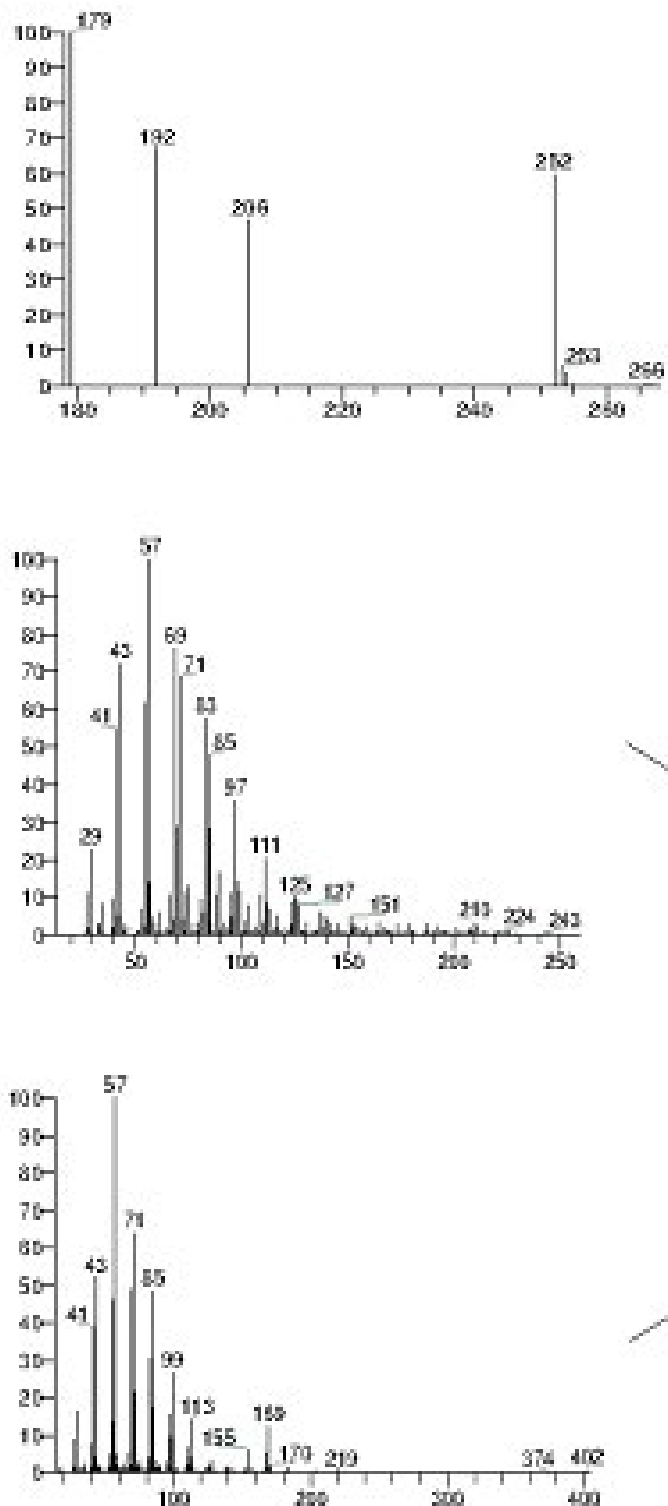

Figure 5: Mass spectrum of molecules as a result of malathion degradation

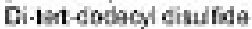

$\int_{400}^{400}$
Methyl 2-3Dimethoxyphoaphorylt-2 (1,2,3-thiadiazol -4:yl)ocotsto Formula C7H iNeOSPS, MW $2 \mathrm{BE}$, CASA NA, Erilya 295.113

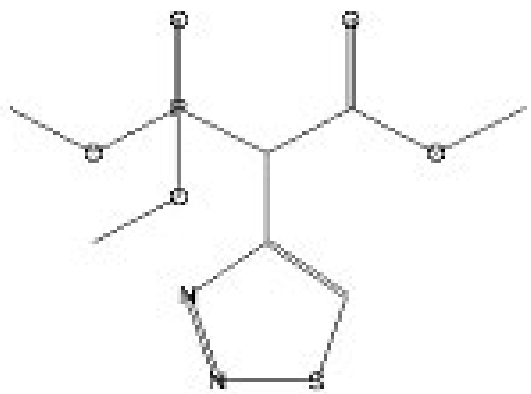

1at. Hexadscangihis

Fonte C16H3LS, MW 2SB. CASe 25360-09.2, Entrya 23375

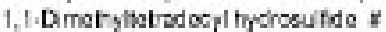

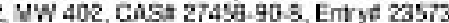

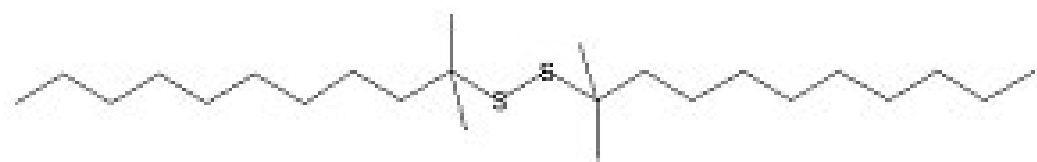

\begin{tabular}{|c|c|c|c|c|c|c|}
\hline $\begin{array}{l}\text { Malathion Concentration } \\
(\mu \mathrm{g} / 100 \mathrm{~mL})\end{array}$ & Lignin & $\begin{array}{l}\text { Malathion Rest } \\
\text { quantity }\end{array}$ & Malathion Degradation \% & $\operatorname{Lip}_{(\mathrm{U} / \mathrm{ml})}$ & $\begin{array}{l}\text { Laccase } \\
(\mathrm{U} / \mathrm{ml})\end{array}$ & $\begin{array}{l}\text { MnPase } \\
(\mathrm{U} / \mathrm{ml})\end{array}$ \\
\hline \multirow[t]{2}{*}{ Control } & - & 0.00 & 0.00 & $0.39 \pm 0.02$ & $3.78 \pm 0.3$ & $0.56 \pm 0.12$ \\
\hline & + & 0.00 & 0.00 & $0.76 \pm 0.01$ & $6.95 \pm 0.03$ & $0.88 \pm 0.10$ \\
\hline \multirow[t]{2}{*}{25} & - & 5.56 & 77.76 & $0.51 \pm 0.03$ & $4.30 \pm 0.03$ & $0.57 \pm 0.09$ \\
\hline & + & 4.05 & 83.80 & $0.79 \pm 0.05$ & $8.32 \pm 0.05$ & $0.89 \pm 0.07$ \\
\hline \multirow[t]{2}{*}{50} & - & 14.60 & 70.80 & $0.57 \pm 0.01$ & $3.22 \pm 0.06$ & $0.59 \pm 0.12$ \\
\hline & + & 12.89 & 74.22 & $0.99 \pm 0.02$ & $8.21 \pm 0.03$ & $0.87 \pm 0.10$ \\
\hline \multirow[t]{2}{*}{100} & - & 41.89 & 58.11 & $0.36 \pm 0.04$ & $3.21 \pm 0.04$ & $0.47 \pm 0.08$ \\
\hline & + & 35.67 & 64.33 & $0.93 \pm 0.04$ & $5.90 \pm 0.03$ & $0.62 \pm 0.06$ \\
\hline
\end{tabular}

Control, growth medium without Malathion; (+) growth medium with Lignin; (-), growth medium without Lignin; peroxidase (Lip), manganese peroxidase (MnPase) Table 2: Degradation of Malathion at different concentrations in growth medium amended with lignin. 
Citation: Ganash MA, Abdel Ghany TM (2016) Pleurotus ostreatus as a Biodegradator for Organophosphorus Insecticide Malathion. J Environ Anal Toxicol 6: 369. doi:10.4172/2161-0525.1000369

Page 6 of 6

decomposition of insecticide malathion on the laboratory level.

\section{Acknowledgements}

Authors would like to acknowledge Regional Center for Mycology and Biotechnology Al Azhar University, Cairo, Egypt.

\section{References}

1. Karalliedde L, Senanayake N (1999) Organophosphorus insecticide poisoning. $\mathrm{J}$ Int Fed Clin Chem 11: 4-9.

2. Sogorb MA, Vilanova E, Carrera V (2004) Future applications of phosphotriesterases in the prophylaxis and treatment of organophosporus insecticide and nerve agent poisonings. Toxicol Lett 151: 219-233.

3. McConnell R, Pacheoco F, Wahlberg K, Klein W, Malespin O, et al. (1999) Subclinical health effects of environmental pesticide contamination in a developing country: cholinesterase depression in children. Environ Res 81: 87-91.

4. Cisar JL, Snyder GH (2000) Pesticides in Percolate, Thatch, Soil, and Clippings and Approaches to Reduce Fenamiphos and Fenamiphos Metabolite Leaching. ACS Symp Series 743: 106-126.

5. Tse H, Comba M, Alaee M (2004) Method for the determination of organophosphate insecticides in water, sediment and biota. Chemosphere 54: 41-47.

6. Singh B, Kaur J, Singh K (2012) Biodegradation of malathion by Brevibacillus sp. strain KB2 and Bacillus cereus strain PU. World J Microbiol Biotechnol 28 1133-1141.

7. Chambers WH (1992) Organophosphorous compounds: an overview. In: Chambers JE, Levi PE (Eds) Oranophosphates, Chemistry, Fate, and Effects. Academic Press, San Diego, pp: 3-17.

8. Barlas NE (1996) Toxicological assessment of biodegraded malathion in albino mice. Bull Environ Contam Toxicol 57: 705-712.

9. Singh BK, Walker A (2006) Microbial degradation of organophosphorus compounds. FEMS Microbiol Rev 30: 428-471.

10. Nath G, Srivastava MK (1999) Effect of processing on the removal of malathion from treated cabbages (Brassica oleracea L. var. capitata). Indian J Ent 52: 300-309

11. Edwards D (2009) Reregistration Eligibility Decision for Malathion. US Environmental Protection Agency - Prevention, Pesticides and Toxic Substances EPA 738-R-06-030, p: 9.

12. Pradnya PK, Bharati JB, Neelima MD, Seema SS (2004) Biodegradation of Organophosphorus Pesticides. Proc Indian Nat Sci Acad 70: 57-70.

13. Chalamala R, Mitta MN, Muppala GP (2012) Mycodegradation of malathion by a soil fungal isolate, Aspergillus niger. International Journal of Basic and Applied Chemical Sciences 2: 108-115.

14. Ahmed HM, Aly SD, El-Sayed BB, Ismail I, El-Fakharany M (2007) Bioremediation of Malathion in Aquatic System by Different Microbial Isolates. J Pest Cont \& Environ Sci 15: 13-28.

15. Arora DS, Chander M, Gill PK (2002) Involvement of lignin peroxidase, manganese peroxidase, and laccase in degradation and selective ligninolysis of wheat straw. Int Biodeterior Biodegrad 50: 115-120.

16. Turlo J, Turlo A (2013) Application of mushroom cultures and isolated enzymes for biodegradation of organic environmental pollutants. Military Pharmacy and Medicine 3: 27-36

17. Sánchez C (2010) Cultivation of Pleurotus ostreatus and other edible mushrooms. Appl Microbiol Biotechnol 85: 1321-1337.

18. Cameron MD, Timofeevski S, Aust SD (2000) Enzymology of Phanerochaete chrysosporium with respect to the degradation of recalcitrant compounds and xenobiotics. Appl Microbiol Biotechnol 54: 751-758.

19. Esposito E, Canhos PV, Duran N (1991) Screening of lignin degrading fungi for removal of color from kraft mill waste water with no additional carbon source. Biotechnol Lett 13: 571-576.

20. Reddy CA (1995) The potential for white-rot fungi in the treatment of pollutants. Curr Opin Biotechnol 6: 320-328.

21. D'Annibale A, Crestini C, Vinciguerra V, Sermanni GG (1998) The biodegradation of recalcitrant effluents from an olive mill by a white-rot fungus. J Biotechnol 61: 209-218.
22. Rodríguez E, Pickard MA, Vazquez-Duhalt R (1999) Industrial dye decolorization by laccases from ligninolytic fungi. Curr Microbiol 38: 27-32.

23. Zhang A, Fang L, Wang J, Liu W (2013) Enzymatic decolorization of Orange II: optimization by response surface methodology and pathway. Environ Prog Sustain Energy 32: 294-301.

24. Singh B, Kaur J, Singh K (2014) Microbial degradation of an organophosphate pesticide, malathion. Crit Rev Microbiol 40: 146-154.

25. Field TM, Grizzle N, Scafidi F, Abrams S, Richardson S (1996) Massage therapy for infants of depressed mothers. Infant Behaviour and Developmt 19 : 109-114.

26. Garzillo AM, Colao MC, Buonocore V, Oliva R, Falcigno L, et al. (2001) Structural and kinetic characterization of native laccases from Pleurotus ostreatus, Rigidoporus lignosus, and Trametes trogii. J Protein Chemistry 20: 191-201.

27. Abbas M, Yadegar A (2015) The Influence of Pesticides and Herbicides on the Growth and Spore Germination of T. harzianum. Agriculture Science Developments 4: 41-44.

28. Smith RJ, Bryant RG (1975) Metal substitutions incarbonic anhydrase: a halide ion probe study. Biochem Biophys Res Commun 66: 1281-1286.

29. Sang BI, Hori K, Tanji Y, Unno H (2002) Fungal contribution to in situ biodegradation of poly(3-hydroxybutyrate-co-3-hydroxyvalerate) film in soil. Appl Microbiol Biotechnol 58: 241-247.

30. Bumpus JA, Tien M, Wright D, Aust SD (1985) Oxidation of persistent environmental pollutants by a white rot fungus. Science 228: 1434-1436

31. Rodriguez E, Guillen NF, Martinez MJ (2004) Degradation of phenolic and nonphenolic aromatic pollutants by four Pleurotus species: Role of laccase and versatile peroxidase. Soil Biol Biochem 36: 909-916.

32. Mougin C, Kollmann A, Jolivalt C (2002) Enhanced production of laccase in the fungus Trametes versicolor by the addition of xenobiotics. Biotechnol Lett 24: $139-142$

33. Kollmann A, Brault A, Touton I, Dubroca J, Chaplain V, et al. (2003) Effect of nonylphenol surfactants on fungi following the application of sewage sludge on agricultural soils. J Environ Qual 32: 1269-1276.

34. Cerniglia CE (1992) Biodegradation of polycyclic aromatic hydrocarbons Biodegradation 3: 351-368

35. Lang E, Nerud F, Novotna E, Zadrazil F, Martens R (1996) Production of ligninolytic exoenzymes and 14C-pyrene mineralization by Pleurotus $\mathrm{sp}$. in lignocellulose substrate. Folia Microbiol 41: 489-493.

36. Pointing SB (2001) Feasibility of bioremediation by white-rot fungi. App Microbiol Biotechnol 57: 20-33.

37. Nerud F, Zouchova Z, Miourkova Z (1991) Ligninolytic properties of different white-rot fungi. Biotechnol Lett 13: 657-660.

38. Van Eerd LL, Hoagland RE, Zablotowicz RM, Hall JC (2003) Pesticide metabolism in plants and microorganisms. Weed Sci 51: 472-495.

39. Ortiz-Hernández ML, Sánchez-Salinas E, Olvera-Velona A, Folch-Mallol JL (2011) Pesticides in the Environment: Impacts and its Biodegradation as a Strategy for Residues Treatment. En: Pesticides-Formulations, Effects, Fate. Stoytcheva M (Eds) In Tech Croatia, pp: 551-574.

40. Xie S, Liu J, Li L, Qiao C (2009) Biodegradation of malathion by Acinetobacter johnsonii MA19 and optimization of cometabolism substrates. J Environ Sci (China) 21: 76-82.

41. Kanade SN, Ade AB, Khilare VC (2012) Malathion Degradation by Azospirillum lipoferum Beijerinck. Science Research Reporter 2: 94-103.

42. Abo-Amer AE (2007) Involvement of chromosomally-encoded genes in malathion utilization by Pseudomonas aeruginosa AA112. Acta Microbiol Immunol Hung 54: 261-277.

43. Andleeb S, Qazi JI, Ghauri MA (2013) Isolation of malathion degrading chromogenic Pseudomonas aeruginosa strains from insecticide impregnated soil. Pakistan J Zool 45: 1447-1451.

44. Andleeb S, Asmatullah, Qazi Jl (2014) In-ovo evaluation of bioremediatedmalathion. Punjab Univ J Zool 29: 1-10. 